\title{
PELAKSANAAN TEKNIK SUPERVISI DALAM UPAYA MENINGKATKAN KINERJA GURU DI SMPN 2 JEROWARU
}

\author{
Muhamad Zaril Gapari \\ STIT Palapa Nusantara \\ zagap205@yahoo.co.id
}

\begin{abstract}
Education is one of the universal activities in buman life, wherever there is society, there is education too. Many countries admit that the problem of education is a complicated problem, but all feel that education is a very important task of the State, a nation that wants to progress, build, and try to improve the condition of society and the world, of course, state that education is the key, and without the key their efforts will failed. The objectives of this research which are to be achieved are: (1) To determine the implementation of supervision techniques in an effort to improve teacher performance at SMP Negeri 2 Jerowaru . (2) To determine the impact of supervision to the improved performance tacher SMP Negeri 2 Jerowaru. The type of research used is descriptive qualitative research methods, data collection techniques using interview techniques, observation, and documentation. To obtain data in the field, interviews were conducted with the supervisors and teachers of Jerowaru State Junior High School. The data analysis technique used is the Hubermen and Miells method, namely data reduction, data presentation, and verification or conclusion drawing. The results of this study indicate that in the implementation of the supervision technique, several methods are used, namely, individual techniques and group techniques. Based on these results, intensive coaching efforts are needed in increasing the competence of teachers, school principals, and school supervisors to achieve quality education, starting from improving the quality of the learning process which will ultimately improve the quality of graduates at all types and levels of education.
\end{abstract}

Keywords: Implementation of Supervision Techniques and Teacher Performance

\begin{abstract}
Abstrak : Pendidikan merupakan salah satu kegiatan yang universal dalam kehidupan manusia, dimanapun ada masyarakat, disana pula terdapat pendidikan. Banyak Negara mengakui bahwa persoalan pendidikan merupakan persoalan yang pelik, namun semuanya merasakan bahwa pendidikan tugas Negara yang amat peting, bangsa yang ingin maju, membangun, dan berusaha memperbaiki keadan masyarakat dan dunia, tentu menyatakan bahwa pendidikan merupakan kunci, dan tanpa kunci usaha mereka akan gagal. Tujuan penelitian ini yang ingin dicapai adalah: (1) Untuk mengetahui pelaksanaan teknik supervisi dalam upaya meningkatkan kinerja guru di SMP Negeri 2 Jerowaru. (2) Untuk mengetahui dampak supervisi terhadap peningkatan kinerja guru di SMP Negeri 2 Jerowaru. Jenis penelitian yang digunakan adalah metode penelitian kualitatif deskriptif, Teknik pengumpulan data menggunakan teknik Wawancara, Observasi, dan Dukomentasi. Untuk memperoleh data di lapangan dilakukan dengan kegiatan wawancara terhadap supervisior dan guru-guru SMP Negeri Jerowaru. Teknik analisis data yang dipergunakan adalah menggunakan metode Hubermen dan Miells, yaitu reduksi data, penyajian data, dan Verifikasi atau Penarikan Kesimpulan. Hasil penelitian ini menunjukkan bahwa dalam kegiatan pelaksanaan teknik supervisi menggunakan beberapa macam cara yaitu, teknik perseorangan dan teknik kelompok. Berdasarkan hasil tersebut diperlukan upaya pembinaan
\end{abstract}

Manazhim : Jurnal Manajemen dan Ilmu Pendidikan

Volume 3, Nomor 1, Februari 2021; 40-51

https:// journal.stitpn.ac.id/index.php/manazhim 
yang intensif dalam meningkatkan kompetensi guru, kepala sekolah, dan pengawas sekolah untuk mewujudkan pendidikan yang bermutu, dimulai dari perbaikan mutu proses pembelajaran yang pada akhirnya akan dapat meningkatkan mutu lulusan pada semua jenis dan jenjang pendidikan.

Kata Kunci: Pelaksanaan Teknik Supervisi dan Kinerja Guru

\section{PENDAHULUAN}

Pendidikan merupakan salah satu kegiatan yang universal dalam kehidupan manusia, dimanapun ada masyarakat, disana pula terdapat pendidikan. Banyak Negara mengakui bahwa persoalan pendidikan merupakan persoalan yang pelik, namun semuanya merasakan bahwa pendidikan tugas Negara yang amat peting, bangsa yang ingin maju, membangun, dan berusaha memperbaiki keadan masyarakat dan dunia, tentu menyatakan bahwa pendidikan merupakan kunci, dan tanpa kunci usaha mereka akan gagal.

Hampir semua orang dikenai pendidikan dan melaksanakan pendidikan, sebab pendidikan tidak terpisah dengan kehidupan manusia. Anak-anak menerima pendidikan dari orang tuanya dan manakala anak-anak sudah dewasa dan berkeluarga mereka akan mendidik anaknya, begitu juga disekolah dan perguruan tinggi, para siswa dan mahasiswa di didik oleh guru dan dosen. Pendidikan merupakan investasi yang paling urgen bagi setiap bangsa, bangsa yang sedang giat membangun. Lancarnya pembangunan disuatu bangsa ditentukan oleh mutu pendidikan.

Mutu pendidikan sangat tergantung pada komponen-komponen yang tardapat dalam pendidikan, diantara komponen yang sangat mempengaruhi berhasil tidaknya pendidikan adalah tergantung dari kualitas guru dengan kata lain guru harus professional.

Dari berbagai literatur yang sudah peneliti telusuri bahwa salah satu upaya yang dapat meningkatkan kualitas guru ialah supervisi pendidikan. Istilah supervisi pendidikan sering diartikan dalam kategori pembekuan mental, karena supervisi juga disebut pengawas atau kepengawasan. Supervisi adalah usaha dari petugas-petugas sekolah dalam memimpin guru-guru dan petugas lainnya, dalam memperbaiki pengajaran, termasuk menstimulir, menyeleksi pertumbuhan jabatan dan perkembangan guru-guru dan merevisi tujuan-tujuan pendidikan, bahanbahan 
pengajaran, metode mengajar, dan evaluasi pengajaran. ${ }^{1}$ Pendapat lain mengemukakan supervisi adalah aktivitas menentukan kondisi-kondisi atau syaratsyarat yang esensial, yang akan menjamin tujuan-tujuan pendidikan. ${ }^{2}$

Kualitas proses belajar mengajar sangat dipengaruhi oleh kualitas kinerja guru. Oleh karena itu, usaha peningkatan kemampuan guru dalam melaksanakan proses belajar mengajar, perlu secara terus menerus mendapatkan perhatian dari penanggung jawab sistem pendidikan.

Tujuan pembelajaran yang diinginkan tentu yang optimal, oleh karena itu untuk mencapai tujuan yang optimal perlu memperhatikan pendekatan pembelajaran yang dapat mencakup, ada beberapa hal yang perlu diperhatiakan oleh pendidik salah satu diantaranya adalah metode mengajar, dimana mengajar merupakan istilah kunci yang hampir tidak perna luput dari pembahasan mengenai pendidikan karena keeratan antara keduanya.

Sekolah merupakan institusi pendidikan yang didalamnya ada pengajar, peserta didik dan supervisior, seorang guru perlu menerapkan metode pengajaran yang tepat serta kecakapan pengajar dalam menerapkan keahlian dan keterampilan yang dimiliki guna tercapainya apa yang diinginkan dari visi dan misi dari sekolah tersebut. Dalam hal ini supervisior perlu selalu memantau dan membina guru dalam penggunaan metode mengajar. Dalam melakukan pembinaan tersebut salah satu teknik supervisi yang digunakan adalah teknik supervisi individual yang memiliki manfaat secara langsung oleh guru yang melaksanakan kegiatan belajar mengajar di kelas.

Guru merupakan komponen sumber daya manusia yang harus dibina agar dapat melakukan fungsinya secara professional, selain itu pengaruh perubahan yang serba cepat mendorong guru-guru untuk terus menerus belajar, menysuaikan diri dengan perkembangan ilmu pengetahuan dan teknologi serta mobilitas masyarakat.

1 Supervisi Aceh. Pengertian Supervisi Pendidikan Makalah, Tujuan, Ruang Lingkup. http://supervisiaceh2012.blogspot.com/2013/05/pengertiansupervisipendidikanmakalah.html . 12 April 2013.

2 M. Ngalim Purwanto. Administrasi dan Supervisi Pendidikan. (PT. Remaja Rosdakarya Bandung, 2009), 76. 
Dari hal inilah supervisi itu penting dilakukan guna meningkatkan sumber daya guru yang professional. ${ }^{3}$

Kenyataan yang ada saat ini supervisi kurang maksimal dilakukan, karena sebagai kepala sekolah belum pandai-pandai membagi waktunya dalam bekerja, sebagian besar waktunya digunakan untuk mengerjakan tugas rutinnya di kantor sedangkan guru-guru tidak cukup mendapatkan pengawasan yang baik dalam proses pembelajaran, atau melaksanakan pengawasan hanya sekedarnya saja tanpa adanya upaya mengembangkan dan memperbaiki cara kerja tenaga mengajar atau kepala sekolah membiarkan cara kerja guru bekerja dengan sendirinya tanpa adanya pengawasan, sehingga banyak guru yang sering datang terlambat, guru tidak hadir tanpa adanya pemberitahuan sebelumnya, guru hanya mengutamakan urusan pribadi dari pada pengabdian, guru mengajar tanpa persiapan, jarang memeriksa tugas rumah siswa, dan malas memberikan evaluasi kepada siswa, dan masih banyak guru yang belum memahami cara menyusun administrasi yang berkaitan dengan kurikulum saat ini. Sebagaimana kita ketahui bersama, bahwa saat ini telah diberlakukan kurikulum baru yang disebut K13. Sementara di SMP Negeri 2 Jerowaru untuk kelas II dan III menerapkan kurikulum KTSP. Sebagai akibatnya para guru, dalam keadaan belum benar-benar memahami cara menyusun administrasi model baru yang berkenaan dengan K13.

Kaitan dengan itulah maka penulis mengambil judul tentang "Pelaksanaan Teknik Supervisi Dalam Upaya Meningkatkan Kinerja Guru di SMP Negeri 2 Jerowaru.

\section{METODE PENELITIAN}

Jenis penelitian yang digunakan adalah penelitian kualitatif yaitu yang akan meneliti obyek sosial yang bersifat alamiah tentang pelaksanaan teknik supervisi dalam upaya meningkatkan kinerja guru di SMP Negeri 2 Unter Iwes. Penelitian ini bersifat kualitatif deskriptif, karena bertujuan untuk mendeskripsikan atau melukiskan realitas sosial dengan kompleks yang ada di sekolah mengenai pelaksanaan teknik

${ }^{3}$ Sahertian, Piet A.. Konsef Dasar dan Teknik Supervisi Pendidikan Dalam Rangka Pengebangan Sumber Daya Manusia. (Jakarta: Rineka Cipta . 2000), 1. 
supervisi. ${ }^{4}$ Obyek yang alamiah obyek yang berkembang apa adanya, tidak di manipulasi oleh peneliti dan kehadiran peneliti tidak mempengaruhi dinamika pada obyek tersebut.

Pendekatan penelitian ini, peneliti menggunakan pendekatan kualitatif. Pendekatan kualitatif merupakan prosedur penelitian yang menghasilkan data deskriptif berupa kata-kata tertulis maupun lisan dari orang-orang dan prilaku yang diamati. $^{5}$

Pendekatan kualitatif adalah penelitian yang menggunakan latar ilmiah, dengan maksud menafsirkan fenomena yang terjadi dan dilakukan dengan jalan melibatkan dengan metode yang ada. ${ }^{6}$

Dengan demikian dapat dikatakan bahwa penelitian kualitatif dilakukan pada kondisi alamiah dan bersifat penemuan dimana peneliti adalah instrumen kunci. Oleh karena itu, peneliti harus memiliki bekal teori dan wawasan yang luas untuk dapat bertanya, menganalisis, dan mengkontruksi objek yang diteliti menjadi lebih luas.

Tujuan penelitian ini adalah untuk mengetahui pelaksanaan teknik supervisi dampak supervisi terhadap peningkatan kinerja guru di SMP Negeri 2 Jerowaru.

Responden dalam penelitian ini adalah guru-guru SMP Negeri 2 Jerowaru yang berperan aktif dalam melakukan proses belajar mengajar (PBM) Selain dari beberapa guru sebagai subyek dan responden penelitian. Peneliti juga mencari sumber data pendukung kepada stap tata usaha dan siswa yang berkenaan dengan teknik supervisi yang dilakukan oleh kepala sekolah dalam meningkatkan kinerja guru. Dalam penelitian ini, sumber data menggunakan (1) Data primer, karena merupakan data yang diperoleh secara langsung melalui wawancara kepada guru-guru untuk mengetahui hasil supervisi yang dilakukan oleh kepala sekolah terhadap guru, (2) Data sekunder, dalam penelitian ini adalah data hasil supervisi kepala sekolah terhadap guru mata pelajaran lain. Metode pengumpulan data penelitian ini dengan Intervie/wawancara, observasi dan dokumentasi. Pemeriksahan keabsahan data ini dengan tringulasi. Sedangkan teknik analisis data penelitian ini adalah reduksi data, penyajian data dan penarikan kesimpulan atau verifikasi.

${ }^{4}$ Sugiono. Metode Penelitian Kuantitatif, Kualitatif, R \& D. (Bandung: Alfabeta, 2010), 79.

5 . Metode Penelitian Bisnis. (Alvabeta, CV 2009), 8.

${ }^{6}$ Moleong, J. Lexi. Metode Penelitian Kualitatif. (PT. Remaja Rosdakarya Bandung 2009), 5-6. 


\section{HASIL PENELITIAN}

Adapun hasil dari penelitian ini dalam pelaksanaan teknik supervisi dalam upaya meningkatkan kinerja guru adalah

\section{Keadaan Guru}

Guru merupakan orang yang bertanggung jawab dalam pelaksanaan proses belajar mengajar Guru berkewajiban menyajikan dan menjelaskan pelajaran, membimbing dan mengarahkan siswa kearah pencapain tujuan pengajaran, dalam hal ini dibutuhkan kemampuan yang profesionalisme seorang guru dalam menjalankan tugasnya. Oleh karena itu, kualitas dan kapasitas dan kualitas guru merupakan faktor yang paling penting sehingga dapat meningkatkan mutu pendidikan. Adapun jumlah guru yang menjadi pupolasi dalam dalam penelitian ini di SMP Negeri 2 Jerowaru sebanyak 13 orang, semuanya masih aktif menjadi tenaga pengajar di SMP Negeri 2 Jerowaru, dan masing-masing guru mempunyai peran dan tugas yang sama dalam hal mendidik dan membimbing siswa, melihat jabatan yang di sandang oleh masingmasing guru di SMP Negeri 2 Jerowaru. Namun juga dapat dikatakan SMP Negeri 2 Jerowaru masih kekurangan guru, itu di lihat dari adanya guru yang memegang mata pelajaran lebih dari satu.

Dan adanya pembagian tugas mengajar memegang lebih dari satu bidang studi, hal ini merupakan suatu kewajaran yang sering terjadi pada tiap-tiap sekolah. Adapun guru yang memegang lebih dari satu mata pelajaran, yang memungkinkan untuk lebih meningkatkan profesi dalam melaksanakan tugasnya sehari-hari. Hal ini bukan berarti bahwa guru yang memegang lebih dari satu bidang studi merasa dirinya lebih mampu mengajarkan mata pelajaran tersebut, akan tetapi karena semua guru/pendidik memiliki tugas dan tanggung jawab yang sama besarnya dalam mencetak generasi yang siap pakai dalam segala bidang.

\section{Keadaan Sarana dan Prasarana}

Disamping sektor guru, pegawai dan siswa, faktor sarana dan prasarana juga tidak kalah penting dalam menunjang lancarnya proses belajar mengajar. Alat peraga atau alat pembelajaran merupakan faktor penunjang yang penting. Artinya untuk mempermudah ketercapainya pembelajaran siswa terhadap pelajaran yang dipelajari. Adapun sarana dan prasarana yang terdapat di SMP Negeri 2 Unter Iwes sebagai salah satu lembaga pendidikan mempunyai 9 ruang teori/kelas, 1 ruang untuk TU, 
dan perpustakaan 1 dan Ruang keterampilan 1. Ruang guru dan TU, menurut pengamatan peneliti, buku-buku diletakkan dalam satu ruangan yaitu ruang kepala sekolah, dan begitu juga dengan ruang guru dan TU terletak pada satu tempat dan hanya dibatasi dengan lemari, tetapi hal itu tidaklah menjadi penghalang untuk kelancaran proses belajar mengajar di SMP Negeri 2 Jerowaru karena semua itu tersusun dengan rapi dan luas ruangan cukup untuk menata barang-barang dan tempat duduk para guru.

\section{PEMBAHASAN}

Berdasarkan data penelitian dari hasil wawancara, observasi dan dokumentasi yang telah dilakukan oleh peneliti sebagaimana obyek peneliti dalam melakukan penelitian tentang Pelakasanaan Teknik Supervisi dalam Upaya Meningkatkan Kinerja Guru di SMP Negeri 2 Jerowaru Kabupaten Lombok Timur maka dapat disajikan sebagai berikut:

\section{Pelaksanaan Supervisi Dalam Meningkatkan Kinerja Guru}

Pelaksanaan teknik supervisi merupakan salah satu cara yangdilakukan oleh supervisior atau lembaga pendidikan. Kepala sekolah SMP Negeri 2 Jerowaru telah melakukan supervisi terhadap guru-guru mata pelajaran atau stap-stap lainnya.

Pelaksanaan teknik supervisi yang dilakukan oleh kepala sekolah adalah teknik peseorangan dan kelompok dalam meningkatkan kinerja guru karena pelaksanaan supervisi oleh supervisor, guru selalu berbuat dan melaksanakan tugas dengan sempurna dalam arti selalu menggunakan metode dan media pembelajaran dalam proses belajar mengajar dan tujuan pembelajaran tercapai dengan menghindari kesalahan serta menjadikan proses belajar mengajar lebih efektif dan efesien. Ini berarti kinerja guru semakin meningkat dengan adanya dua teknik supervisi dari kepala sekolah atau pengawas sekolah SMP Negeri 2 Jerowaru.

Supervisi dapat dilakukan dengan berbagai cara, dengan tujuan agar apa yang diharapkan bersama dapat menjadi kenyataan. Secara garis besar, cara atau teknik supervisi dapat digolongkan menjadi dua, yaitu teknik perseorangan yang dilakukan 
secara individual dan teknik yang bersifat kelompok ialah teknik yang dilakukan untuk melayani lebih dari satu orang. ${ }^{7}$

\section{Masukan-masukan dari Kepala Sekolah Ketika Melakukan Pengawasan}

Dalam proses belajar mengajar seorang kepala sekolah harus memperhatikan langkah-langkah guru-guru yang sedang membimbing dan mengarahkan peserta didik melalui materi atau metode yang digunakannya yang kemudian kepala sekolah melakukan kunjungan kelas atau observasi dalam melihat kekurangan agar dapat memberikan masukan-masukan bagi guru yang merasa kesulitan dalam mengajar peserta didik. Untuk menyelenggarakan dan melaksanakan sangat memerlukan keinsyafan, kesadaran, dan semangat. Dengan kata lain untuk memajukan suatu karya bersama secara keseluruhan adanya kesedian untuk memikul tanggung jawab tampak memikirkan atau mengutamakan kepentingan-kepentingan pribadi melainkan justru untuk tercapainya tujuan-tujuan bersama.

Hasil wawancara yang dilakukan oleh peneliti terhadap kepala sekolah, guru mata pelajaran, stap tata usaha dan siswa, memiliki pendapat yang sama yaitu dapat disimpulkan bahwa dengan adanya masukanmasukan yang diberikan oleh kepala sekolah kepada guru-guru, TU dan siswa dapat meningkan kinerja. Karena dengan adanya teknik supervisi serta masukan-masukan dari kepala sekolah, maka proses pembelajaran di SMP Negeri 2 Jerowaru akan berjalan dengan lancar.

Dalam membina dan mengembangkan potensi sumber daya guru ada dua analisis masalah yang digunakan yaitu sebagai berikut: (1). Masalah-masalah umum yang dihadapi dalam tugas mengajar dan mendidik yang mencakup, membantu guru dalam menterjemahkan kurikulum dari pusat keedalam bahasa belajar mengajar, membantu guru-guru dalam meningkatkan program belajar mengajar, membantu dalam merancangkan program belajar mengajar. Membantu dalam melaksanakan proses belajar mengajar, membantu dalam menilai proses dan hasil belajar mengajar. (2). Masalah-masalah khusus yang dihadapi guru. Masalah-masalah itu antara lain: Membantu guru dalam menghadapi kesulitan dalam mengajar tiap mata pelajaran, mebantu guru dalam memecahkan masalah-masalah pribadi (personal problem),

${ }^{7}$ Ibid, 120. 
membantu guru dalam menghadapi masalah khusus di tiap tingkat mulai dari SD sampai di SMU (instansi tempat dia kerja).

\section{Dampak Pelaksanaan Teknik Supervisi Terhadap Kinerja Guru}

Proses belajar mengajar di SMP Negeri 2 Jerowaru dalam pelaksanaan teknik supervisi guna meningkatkan profesionalisme guru mata pelajaran tidak sepenuhnya berjalan dengan sempurna sebagaimana yang telah direncanakan. Dalam kenyataannya terdapat dampak yang mempengaruhi kinerja guru yaitu guru-guru yang sedang mengajar/menyampaikan suatu materi dalam kelas pada saat itulah supervisior melakukan pengawasan dengan mengadakan kunjungan kelas.

Hasil wawancara yang dilakukan oleh peneliti terhadap kepala sekolah dengan teknik yang dilakukan banyak mendapatkan dampak yang baik setelah kepala sekolah memberikan masukan-msukan kepada guru-guru mata pelajaran maupun stap lain untuk meningkatkan kinerja agar di dalam melaksanakan tugasnya bisa membantu mereka ketika dalam mengalami kesulitan, hal ini sekolah juga mempunyai kebijakan tertentu yang tertuang dalam bentuk tata tertib, siswa dituntut untuk berprilaku sesaui dengan tata tertib yang berlaku disekolahnya untuk mencapai keberhasilan proses belajar mengajar dan membentuk karasteristik siswa agar bertanggung jawab dan disiplin.

\section{Pengaruh Supervisi Terhadap Kinerja Guru}

Supervisi pendidikan sebagai proses pemberian layanan bantuan profesional kepada guru untuk meningkatkan kemampuannya dalam melaksanakan tugas-tugas pengelolaan proses pembelajaran secara efektif dan efisien. Dengan adanya pelaksanaan supervisi oleh kepala sekolah diharapkan memberi dampak terhadap terbentuknya sikap professional guru. Sikap professional guru merupakan hal yang amat penting dalam memelihara dan meningkatkan profesionalitas guru, karena selalu berpengaruh pada perilaku dan aktivitas keseharian guru. Perilaku profesional akan lebih diwujudkan dalam diri guru apabila institusi tempat ia bekerja memberi perhatian lebih banyak pada pembinaan, pembentukan, dan pengembangan sikap professional.

Perpornance kerja itu pada garis besarnya dipengaruhi oleh dua hal, yaitu faktor-faktor individu dan faktor-faktor situasi. Dalam teori atribusi atau Expectancy Theory, dijelaskan bahwa kinerja (Performance) itu dipengaruhi oleh motivasi (motivation) 
dan kemampuan (ability). Menurut teori ini performance adalah hasil intraksi antar motivasi dengan ability (kemampuan dasar). Dengan demikian, orang yang tinggi motivasinya tetapi memiliki ability yang rendah akan menghasilkan performance yang rendah. Begitu pula halnya dengan orang yang sebenarnya berability tinggi tetapi rendah motivasinya. ${ }^{8}$

Kegiatan supervisi kepala sekolah dan motivasi kerja guru akan berpengaruh secara psikologis terhadap kinerja guru, guru yang puas dengan pemberian supervisi oleh kepala sekolah dan motivasi kerjanya tinggi maka ia akan bekerja dengan sukarela yang akhirnya dapat membuat produktivitas kerja guru meningkat. Tetapi jika guru kurang puas terhadap pelaksanaan supervisi yang dilakukan oleh kepala sekolah dan motivasi kerjanya rendah maka guru dalam bekerja kurang bergairah, hal ini mengakibatkan produktivitas guru menurun.

\section{KESIMPULAN}

Beberapa uraian dan hasil penelitian penulis pada lokasi penelitian, maka penulis dapat menarik suatu kesimpulan sebagai berikut:

Pelaksanaan teknik supervisi dalam upaya meningkatkan kinerja guru di SMP Negeri 2 Jerowaru. Pelaksanaan teknik supervisi yang dilakukan oleh kepala sekolah adalah teknik perseorangan dan kelompok dalam meningkatkan kinerja guru karena pelaksanaan supervisi oleh supervisor, guru selalu berbuat dan melaksanakan tugas dengan sempurna dalam arti selalu menggunakan metode dan media pembelajaran dalam proses belajar mengajar dan tujuan pembelajaran tercapai dengan menghindari kesalahan serta menjadikan proses belajar mengajar lebih efektif dan efesien. Ini berarti kinerja guru semakin meningkat dengan adanya dua teknik supervisi dari kepala sekolah atau pengawas sekolah SMP Negeri 2 Jerowaru.

Dampak dari supervisi yang dilakukan oleh supervisor Berdasrkan hasil wawancara diatas bahwa dengan teknik yang dilakukan oleh kepala sekolah banyak mendapatkan dampak yang baik setelah kepala sekolah memberikan masukanmsukan kepada guru-guru mata pelajaran maupun stap lain untuk meningkatkan kineja yang agar di dalam melaksanakan tugasnya bisa membantu guru ketika dalam

8 As'ad, Moh. Seri Imu Sumber Daya Manusia Psikologi Industri, Edisi Keempat, Cetakan Kedelapan. (Yogyakarta: Liberty 2003), 56. 
mengalami kesulitan, hal ini sekolah juga mempunyai kebijakan tertentu yang tertuang dalam bentuk tata tertib, siswa dituntut untuk berprilaku sesaui dengan tata tertib yang berlaku disekolahnya untuk mencapai keberhasilan proses belajar mengajar dan membentuk karasteristik siswa agar bertanggung jawab dan disiplin.

\section{SARAN}

Diharapkan kepada guru-guru selalu berusaha meningkatkan profesinya untuk meningkatkan output pendidikan yang lebih profesional. Supervisi yang dilakukan oleh kepala sekolah sebagai penanggung jawab di bidang pendidikan hedaknya mengangendahkan program supervisi sebagai kegiatan yang merupakan tanggung jawab kepala sekolah, karena dengan supervisi akan sangat bermanfaat untuk membantu guru dalam melaksanakan tugasnya sehari-hari. Dan juga diharapkan kepada peneliti lain yang akan mengadakan penelitian yang sejenis diharapkan dapat mengembangkan hasil penelitian ini terhadap guruguru, untuk membuktikan bahwa dengan adanya supervisi dapat meningkatkan kineja guru yang tercermin dari peningkatan mutu hasil belajar siswa.

Bagi Kepala sekolah, perlu memperjuangkan lembaganya sebagai lembaga yang unggul dan mampu berkompetisi dengan lembaga sekolah lainnya dan mempunyai inovasi baru, kedisiplinan diri dan rasa tanggungjawab, meningkatkan kerjasama dengan berbagai pihak, dalam meningkatkan kinerja untuk mencapai tujuan dan yang lebih efektif dan efisien dengan jalan mengembangkan pendidikan akhlak di madrasah. Para guru atau karyawan, meningkatkan semangat, komitmen dalam usaha mengembangkan pendidikan akhlak di madrasah berupa mendisiplinkan diri dalam pelaksanaan tugas dan kewajibannya serta menjalin hubungan kekerabatan atau kolegial antar warga madrasah secara harmonis.

Upaya untuk meningkatkan hasil belajar siswa dan pelaksanaan manajemen pendidikan akhlak, hendaknya sekolah meningkatkan kerjasamayang baik dengan lembaga-lembaga terkait, orang tua dan masyarakat. 


\section{DAFTAR PUSTAKA}

As’ad, Moh. 2003. Seri Ilmu Sumber Daya Manusia Psikologi Industri, Edisi Keempat. Cetakan Kedelapan. Yogyakarta: Liberty.

M. Ngalim Purwanto,2009. Administrasi dan Supervisi Pendidikan. PT. Remaja Rosdakarya Bandung.

Moleong, J. Lexi. 2009. Metode Penelitian Kualitatif. PT. Remaja Rosdakarya Bandung.

Sahertian, Piet A. 2000. Konsef Dasar dan Teknik Supervisi Pendidikan Dalam Rangka Pengebangan Sumber Daya Manusia. Jakarta: Rineka Cipta.

Supervisi Aceh. 2012. Pengertian Supervisi Pendidikan Makalah, Tujuan, Ruang Lingkup. http://supervisiaceh2012.blogspot.com/2013/05/pengertiansupervisipendidik anmakalah.html . 12 April 2013.

Sugiyono, 2009. Metode Penelitian Bisnis. Alvabeta, CV

2010. Metode Penelitian Kuantitatif, Kualitatif, R \& D. Bandung: Alfabeta 